\title{
Form Follows Culture: Symbolic Feng Shui Logo Design in the Greater China Region
}

\author{
ShawHong SER \\ Department of Communication Management, Faculty of Communication Arts, \\ Chulalongkorn University, \\ Bangkok 10330, Thailand. \\ shaw.h@chula.ac.th
}

\begin{abstract}
The visual identity of a logo has always been one of the major means of expression of social values, and cultural preferences in a particular society. Hence, each area and region logo's design aesthetic is a style characterized by a particular cultural influence that introduces its principles and canons. Accordingly, a logo is not just a representation of a company or business, in order to fully serve its purpose, the logo representation must illustrate what the company does as well as be able to echo with the social, cultural and geographical features of the targeted region. In this paper, to respond to the research scholarly interest in the cultural influences on design, the researcher has made an attempt to study the influence of Feng Shui on logo design in the Greater China region. Based on an in-depth visual-based survey on banks'logo design in the Greater China region, the author identified in this paper one unique design characteristic, namely Symbolic Feng Shui logo design. The result showed that (1) there is substantial cultural values and preference for the logo with the influence and application of Feng Shui. (2) Logos based on concepts and forms (particularly ancient Chinese coins) found in Feng Shui were the most preferred visual representation used by banks in the Greater China region. (3) The Symbolic Feng Shui logo as a unique design language has developed into its distinctive style. It is hoped that this paper will provide insights into an understanding of the impact of traditional culture on modern design, particularly on Feng Shui cultureinspired logo design in the Greater China region.
\end{abstract}

Keywords - Culture-inspired design; Symbolic Feng Shui Logo; Form follows Culture; Logo design; The Greater China region.

\section{INTRODUCTION}

The term "culture" has been defined in diverse definitions under different academic disciplines and domains knowledge. Over the centuries, definitions of the term "culture" have been continually refining and redefined under the variability of context. For instance, in the 19th century, under the influence of the Romantic movement and the rise of nationalism, culture come to be associated with "the specific and variable cultures of different nations and peoples (Du Gay et al., 2013). In the 20th century, culture is associated with the rise of the human and social sciences. As given contexts determine the meaning of the term, with such complexity, "culture" is indeed a difficult concept to be unitarily defined and a complicated subject to be studied. Lin (2007), different definitions of culture reflect different theories for understanding or criteria for evaluating human activity. However, in a broad sense, the term "culture" includes many elements, such as belief systems, traditions, language, customs, rules, norms and ways of communicating. Therefore, culture could be scope as the way an entire society lives and its organization. Afzal (2017), culture is a powerful concept that influences much more than one often realizes. Whether it is the culture by birth or the cultures of by learn, it plays a significant role in every aspect of the society that one's live in. In brief, culture is woven into every aspect of one's life, as culture is ubiquitous.

Throughout history, cultural influences have played significant roles in the development of artistic practices and determining the aesthetic value. Bruyn (2002), art is uniquely generated in social contexts with distinct values for people who are different in their ethnicity, race, and gender. People develop a distinctive aesthetic 
value based on their terms and cultural context. Culture influence a nation and its society on artistic expressions and preferences, for instance, aesthetic conceptions of traditional Chinese painting is influenced by the Taoist and Confucius humanities, Japanese ink monochrome painting is influenced by Zen philosophy, Thai temple frescos are influenced by Buddhist cosmology and culture, etc. Meanwhile, for design, since many centuries ago, the phenomenon of expressing cultural inspirations in design products has been widely practiced in many parts of the world. For instance, in Asia, Chinese blue and white pottery decoration have been inspired by cultural symbolism that is inherent in Chinese philosophy. Persian carpet design with a design of exotic eastern flair reflects its distinctive Islamic cultural sensibility; the Japanese cultural concept of "Wabi-sabi" is embedded in Japanese porcelain and ceramic design, and Thai Benjarong porcelain with stylized Thai motifs inspired by the cultural legacy of Siamese tradition. Briefly, one's concepts in aesthetic are shaped and reflect from one's concept of culture. This is not to say that culture is responsible for every aspect of one's aesthetic values, yet to a certain extent, culture does inspire and influence of society on aesthetic preferences.

Cultural difference in artistic expression and preference is correlated with cultural and social practices (Bao, 2016). As a pattern of ideas, culture is learned and passed on through generations, and as a source of creativity and innovativeness, culture-inspired artists and designers in producing artworks with distinctive cultural expression and identity. Meanwhile, as culture is a dynamic and evolving system, thence, culture is fluid rather than fixed, and consequently, creative talents from diverse historical and cultural contexts respond to culture as a source of inspiration in their unique manners. Because of this, throughout history, artists and designers from different parts of the world have articulated their distinctive cultural manifestation and artistic style in their creative outputs. For design practices in particular, under the notion of "culture-inspired design", the design language has been rooted in expressing cultural meanings through an approach of "form follows culture". As such, for culture-inspired design, culture influences design inspiration and evaluation, simultaneously, cultural messages disseminate through design products. Culture and design, therefore, established a symbiotic relationship and function by depending on each other.

\section{METHODS}

\section{The Relationship Between Culture and Design}

According to Carlson and Richards (2011), design and culture have always been closely interrelated... the design has become the embodiment of a larger process of creative 'culture-mongering' that has become a means to capture ideation, innovation, and enterprise and made to stand for cultural identity. Lin (2007), in the global market-local design era, connections between culture and design have become increasingly evident. Designing culture into products will become a design trend in the global market. So to speak, in the era of "Glocalization", for design, culture plays a significant role in value-adding and creates the core of product value. The same is true for culture, in which design is the crucial force in enforcing 'cultural permaculture'. Briefly, $21^{\text {st }}$ century's designers are given an important role as "culturist", which requires them to have a good consideration in designing their cultural identity, meanings, and values through the medium of design.

Since the new millennium, the impacts of globalization permeate all facets of society. Lee (2004) observes that globalization has made culture the most important asset to work with. Apparently, that culture has become a critical issue to deal with; hence, designers are no exception from this paradigm. Lin (2007), designers have noted the importance of associating products with cultural features in order to enhance product value, and transforming local cultural features into design elements has become a creative strategy for "product identity" in the global market. At this point, particularly in the field of industrial design, culture-inspired design philosophy has played an important role in embedding cultural elements into products and in increasing their cultural value in the competitive global product market. Lin (2007) concluded that, as culture plays an important role in the field of design, the practice of culture-oriented design would become one of a key point in design evaluation in the future.

In short, under the framework of "culture-inspired design", designers are given challenges to transform cultural features into design elements, which fit into the concept of "form follows culture". Designers as culturists are given the challenge to employ or to combine the knowledge of indigenous culture into contemporary design language for the sustainability of cultural permaculture. 


\section{RESULT AND DISCUSSION}

\section{Form Follow Function}

In 1896, the American architect, Louis Henri Sullivan (1856-1924) coined the phrase "form follows function" to refers to the idea of the shape of structures is dictated by their function in his essay entitled "The Tall Office Building Artistically Considered" (Craven, 2019). Since then, "form follows function", as a manifesto and principle of modern architecture design (particularly to the Chicago School) has become a design philosophy that celebrated by designers across different disciplines. Thus, throughout the $20^{\text {th }}$ century, form follows function has evolved into a driving principle of modernity in the design industry. From industrial design, product design, communication design to other areas of design, functionalism or functional design has developed into the modernist dogma that values "less is more" or functional requirements instead of excessive ornaments.

In simple terms, as a design principle, form follows function suggests that form and function are one. Hence, additional design elements or ornamentation will be considered as superfluous. However, this does not mean that Louis Henri Sullivan's philosophy against all artistic decoration. Wu (2018), the modernists acknowledged the value of aesthetically appealing design, yet that beauty should come from the pursuit of functionality. For that reason, the core principle of form follows function in design is simple and clean, based on rationality and functionality.

Over the years, form follows function as a design principle has been adopted regardless of the design fields. The celebration of this discipline seems to make a lot of sense, as the looks (beauty) and design (form) should be determined by its purpose (function). However, in the postmodern context, this modernist design principle has been inspected and challenge by alternatives design principles such as, "Form follows fashion", "form follows fantasy", "form follows finance". These design disciplines viewed design from entirely different perspectives, for instance, Form follows fashion defined design as cultural products that evolve along with the society, thus, forms should be transformed according to the taste, not merely on purpose. For this reason, forms should not be underestimated, elaborate design and ornaments are not necessarily redundant. Form follows fantasy, on the other hand, interpreted that good design should engage the user's emotion and imagination. Aesthetics influences one's emotions; hence, apart from functions, it is necessary to design feelings into a design.

For Form follows finance, the discipline sees design as a reflection of one's social and financial statuses, lavish design with pricey materials per se are a core consideration for this ideology. By and large, form follows function, as a design philosophy that derives from the modern times; its relevancy in postmodern context has been debate ceaselessly by today's design scholars. According to Jeremiah (2010), after all, it is not really about the function or the form, but the "how" and the "who" that will determine both the function and the form. Whether is form follows function or form follows non-function, a "right design" is highly rely upon one's context.

\section{Form Follows Culture}

As one of the most legendary design philosophies, form follows function has a strong influence on almost every design discipline in the $20^{\text {th }}$ century. Hence, the trace and taste of functional design can be easily sensed and seen from industrial design, product design, and communication design to many other design disciplines. Meanwhile, different design ideologies or sub-ideologies were also founded base on the framework of form follows function. For instance, "Form follows nature" is an alternative discipline that advocates design should be mimic natural forms or integrate with natural settings (Spacey, 2016). According to Kleijn Brand Agency (2015), a design should be considered and utilized by its context; thus, it is not merely about form follows function. The hard question for design is always concerning what is the context, for that reason, it is more about "Form follows context". As a matter of fact, the form of design is concurrently influenced by its function, context, and culture. Therefore, there is no absolute right and wrong on each design ideology; merely as different design ideologies are in fact given a core consideration and attention on a different focus.

For communication design, "Form follows culture" is probably one of the most significant elements that designers and a client cannot afford to overlook. According to Seligman (2013), the form of design is influenced by the culture of its maker, as well as the cultural experience of the users. As such, designing culture into a design is matters more than ever in the global market-local design era. Hormia (2018), brands depend on symbolic representation (e.g. a logo or an icon) to convey meaning, and meaning is culturally constructed and contextdependent. Thus, culture as a design strategy has a significant role to play in brand identity design. 


\section{FormFollows Culture - Feng Shui in Logo Design}

"Feng Shui", literally translates as "wind-water" in English is an ancient Chinese tradition dating back thousands of years. Throughout the centuries, the art of Feng Shui has been used to promote and enhance positive energy. It is believed that proper placement of elements within the home or office helps facilitate the flow of "Qi" (Beauchesne, 2015). Feng Shui, also known as the art of spatial arrangement, has made a great impact on Chinese society (Chen, 2007). Initially, Feng Shui was employed by Chinese astrologers to orient buildings, often spiritually significant structures such as royal mausoleums and tombs. Subsequently, as the practice of Feng Shui developed, the art was also to be applied in architectural features, from the placement of lintels and pillars, doors and windows, to gardens and landscaping. Therefore, Classical Feng Shui was considered by many as mysterious methods or techniques to harmonizing one's with one's surrounding environment (Baldwin, 2016). However, as the art developments over time, today, the practice of Feng Shui is broadly known as an observational study of appearances or natural phenomena through formulas and systematical calculations.

Over the centuries, Feng Shui reflects and shapes most of the Chinese cultural values. Up to the present time, conscious and unconscious influences of Feng Shui penetrate into every aspect of Chinese society, from political, social and culture to personal life (Chen, 2007). For instance, in recent years, a business logo with a touch of Feng Shui has become a creative trend in Asia. According to Cisek (2015), based on the five elements of Feng Shui, implementation of Feng Shui for business logos is an approach to incorporate Feng Shui colors and a shape that is relevant to one's business category. Tchi (2019), in the business context, Feng Shui is implemented for good energy in the work-pace in order to strengthen the well-being of the co-workers, as well as to attract more business success. While these are the most popular Feng Shui applications, people also believe the Feng Shui logo design can improve in leading the best results, which is implementing Feng Shui into the design of the business logo, cooperate identity design and other business marketing materials.

Literally, integrated the arts of Feng Shui in the business logo has been a "design language" widely practiced for decades in the Greater China region (Mainland China, Hong Kong, Taiwan, and Macau). Over the years, the practice of the "Symbolic Feng Shui logo" has developed into its distinctive design language. For instance, many banks' logo design in the Greater China region illustrated the touch of Feng Shui. From the Bank of China, Bank of Taiwan, Hang Seng Bank Hong Kong and Tai Fung Bank of Macau, all indicated the influence and symbolic application of Feng Shui.

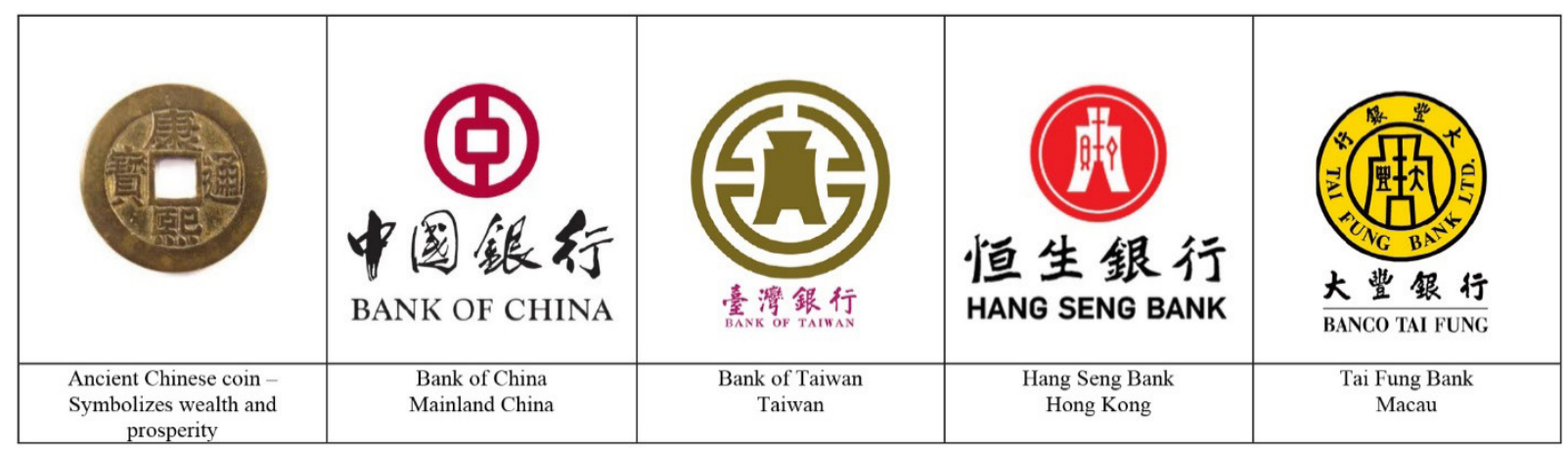

Figure 1 Bank logo designs in the Greater China region

According to Ashkenazy (2013), ancient Chinese coins as one of the most recognized Feng Shui symbols of wealth and good fortune have been widely used in the design of banks' logo in China. For example, the logo of Bank of China, which comprised of a red circle with a square in the middle, the logo references an ancient Chinese coin. This design by Kan Tai-keung from Hong Kong has become an excellent example of the Symbolic Feng Shui application in logo design. Apart from the logo of the Bank of China, the very essence of many banks' logo design in the Greater China region also exhibited the influences of Feng Shui culture. Thus, it is no surprise to see the graphic of ancient Chinese coin is the most widely used symbol in banks' logo design. For example, the logo of the Hua Xia Bank, the design combined an ancient Chinese coin with a dragon motif derived from the Hongshan Culture to symbolize power, wealth and prosperity. The similar design concept also adopted by the Bank of Fushun's logo. Meanwhile, auspicious cultural symbols with Feng Shui signification such as Phoenix and auspicious clouds motif also been widely combined with an ancient Chinese coin in bank logo design, e.g., Wu Xi Rural Commercial Bank, TRC Bank, Bank of Wei Fang and many other examples listed as follow. 


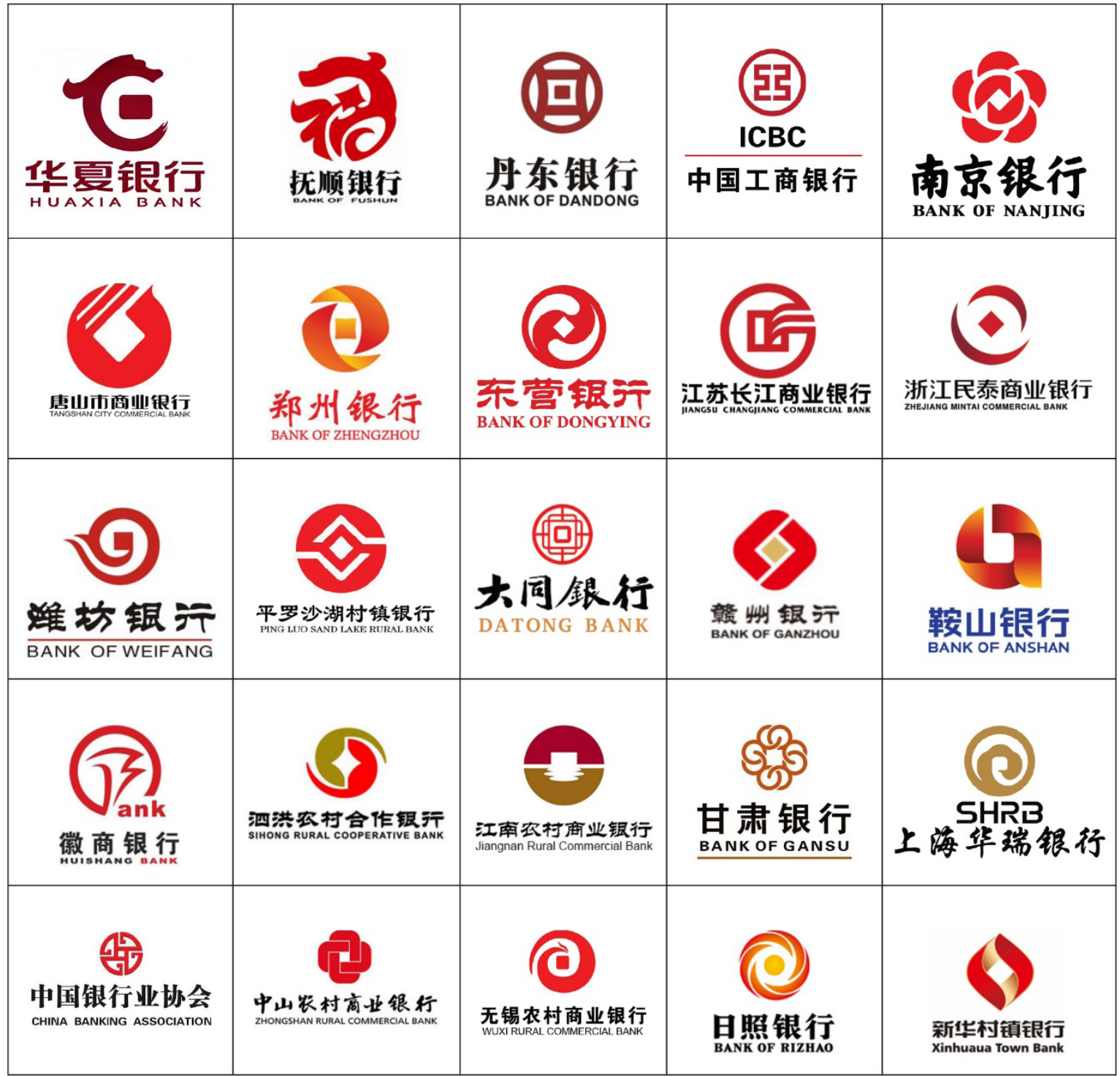

Figure 2 Example of Banks' Logos in China 1

In term of colors selection, red, orange and bronze-yellow as colors symbolizes for good fortune and wealth has been the most popular preference. For agricultural banks or agriculture-related commercial banks, green is commonly used to symbolize wealth and growth. Blue as the color represents advancement and optimism is also another color that has been widely used by banks in China. 


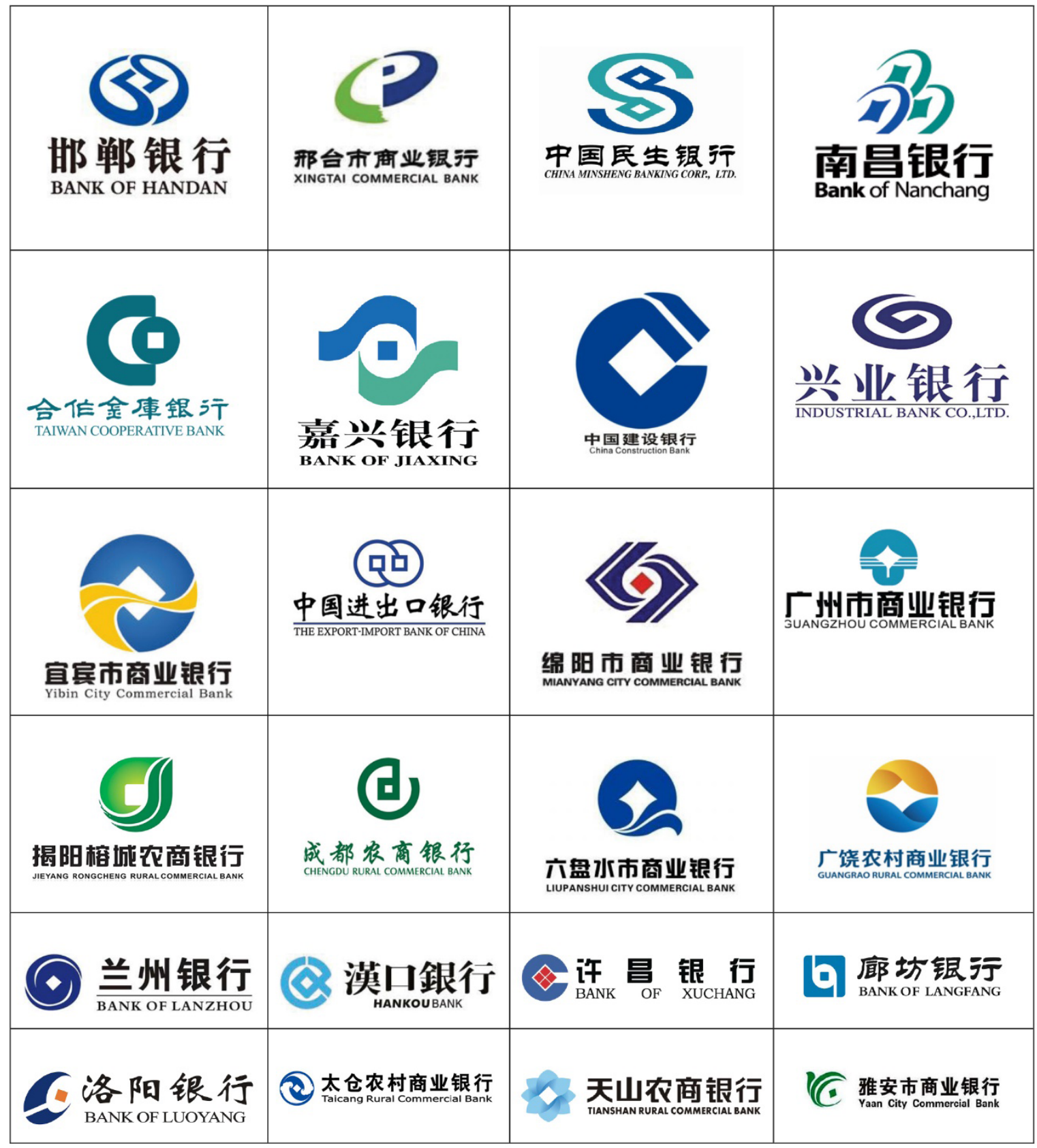

Figure 3 Example of Banks' Logos in China 2

Meanwhile, red as the most popular "auspicious color" in Feng Shui culture is also the most favorite color used by banks' logo design in the Greater China region. Below are examples of bank logo design with a design concept derived from ancient Chinese coin and using red as a dominant color. 


\begin{tabular}{|c|c|c|}
\hline 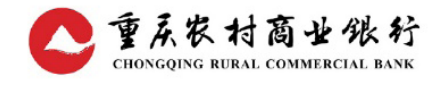 & (A) 东 莞银行 & 武汉农村商业银行 \\
\hline (D) 平顶山银行 & 貄，晋商银行 & $\begin{array}{l}\text { 广州银行 } \\
\text { BANK OF GUANGZHOU }\end{array}$ \\
\hline $\begin{array}{l}\text { 菜商银行 } \\
\text { LAISHANG BANK }\end{array}$ & 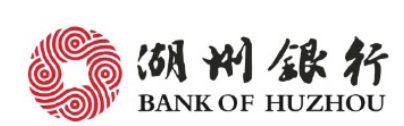 & 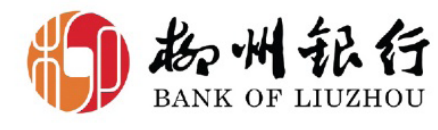 \\
\hline $\begin{array}{l}\text { 青岛银行 } \\
\text { BANKOF QINGDAO }\end{array}$ & 占州市商业银行 & $\begin{array}{l}\text { 由靖市商业全很行 } \\
\text { UIING CITY COMMERCIAL BANK }\end{array}$ \\
\hline 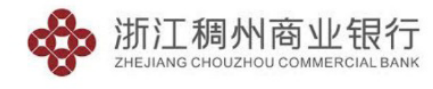 & $\begin{array}{l}\text { 东蓉炎材商业银行 } \\
\text { DRC Bank }\end{array}$ & 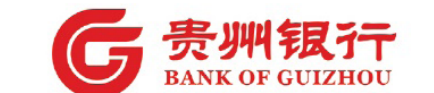 \\
\hline GYB(D) 贵阳银行 & $\begin{array}{l}\text { 辽阳银㲿 } \\
\text { BANK OF LIOYANG }\end{array}$ & 儿江银行 \\
\hline $\begin{array}{l}\text { 乐山市商业银行 } \\
\text { LESHAN CITY COMMERCIAL BANK }\end{array}$ & 山叫商业银行 & $\begin{array}{l}\text { 林市商业 银行 } \\
\text { ILIN CITY COMMERIALBANK }\end{array}$ \\
\hline 广东南舆银行 & $\frac{\text { 承德银行 }}{\text { BANK OF CHENGDE }}$ & 恰商银待 \\
\hline 大连农商银行 & 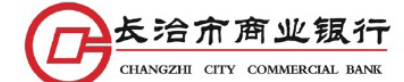 & 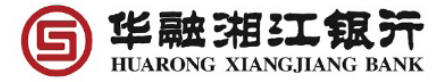 \\
\hline $\begin{array}{l}\text { (華南 銀 jٓ } \\
\text { HUA NAN BANK }\end{array}$ & 大 大连银行 & $\begin{array}{l}\text { 原门市商止很行 } \\
\text { Xiamen City Commercial Bank }\end{array}$ \\
\hline 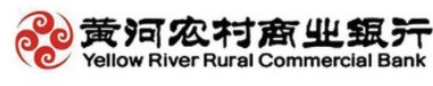 & 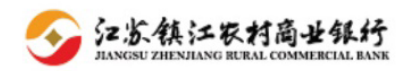 & 哈密市商业银行 \\
\hline $6 \begin{array}{l}\text { 沭阳农村合作银行 } \\
\text { SHUYANG RURAL COOPERATIVE BANK }\end{array}$ & 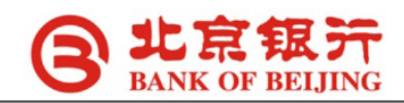 & \\
\hline
\end{tabular}

Figure 4 Example of Banks' Logos in China 3

Apart from the above-mentioned examples; there are also bank logo designs derived from ancient Chinese coin, yet designed in multi-colors to serve its unique context and business preference. 


\begin{tabular}{|c|c|c|}
\hline Q 合萌科技农村商业银行 & 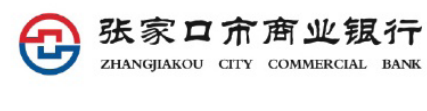 & $\begin{array}{l}\text { 广西北部湾银行 } \\
\text { GUANGXI BEIBU GULLF BANK }\end{array}$ \\
\hline $\begin{array}{l}\text { (2) 第一銀行 } \\
\text { First Bank }\end{array}$ & 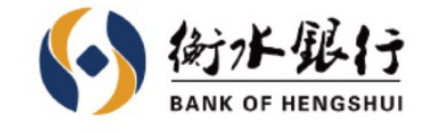 & 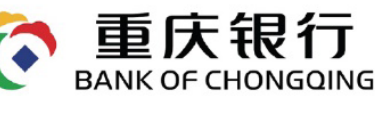 \\
\hline $\begin{array}{l}\text { 紫金农商银行 } \\
\text { ZIJIN RURAL COMMERCIAL BANK }\end{array}$ & $\begin{array}{l}\text { 桂林银行 } \\
\text { GUILIN BANK }\end{array}$ & $\begin{array}{l}5 \text { 公州银行 } \\
\text { TZB 简单方便快捷 }\end{array}$ \\
\hline
\end{tabular}

Figure 5 Example of Banks' Logos in China 4

In addition to the above-mentioned examples, the ancient Chinese spade money (used during the Zhou dynasty of China, 1045 to 256 BC) is another popular symbolic association of the Feng Shui element for banks' logo in the Greater China region. For instance, the logo's design of the Central Bank of the Republic of China, Bank of Taiwan, Hang Seng Bank of Hong Kong, and Tai Fung bank of Macau are inspired by spade money from the Warring States period. Meanwhile, many other banks also employed spade money as an auspicious element for their logo design, for example, Zao Zhuang Bank, Bank of Bao Ding, Da Tong City Commercial Bank, etc.

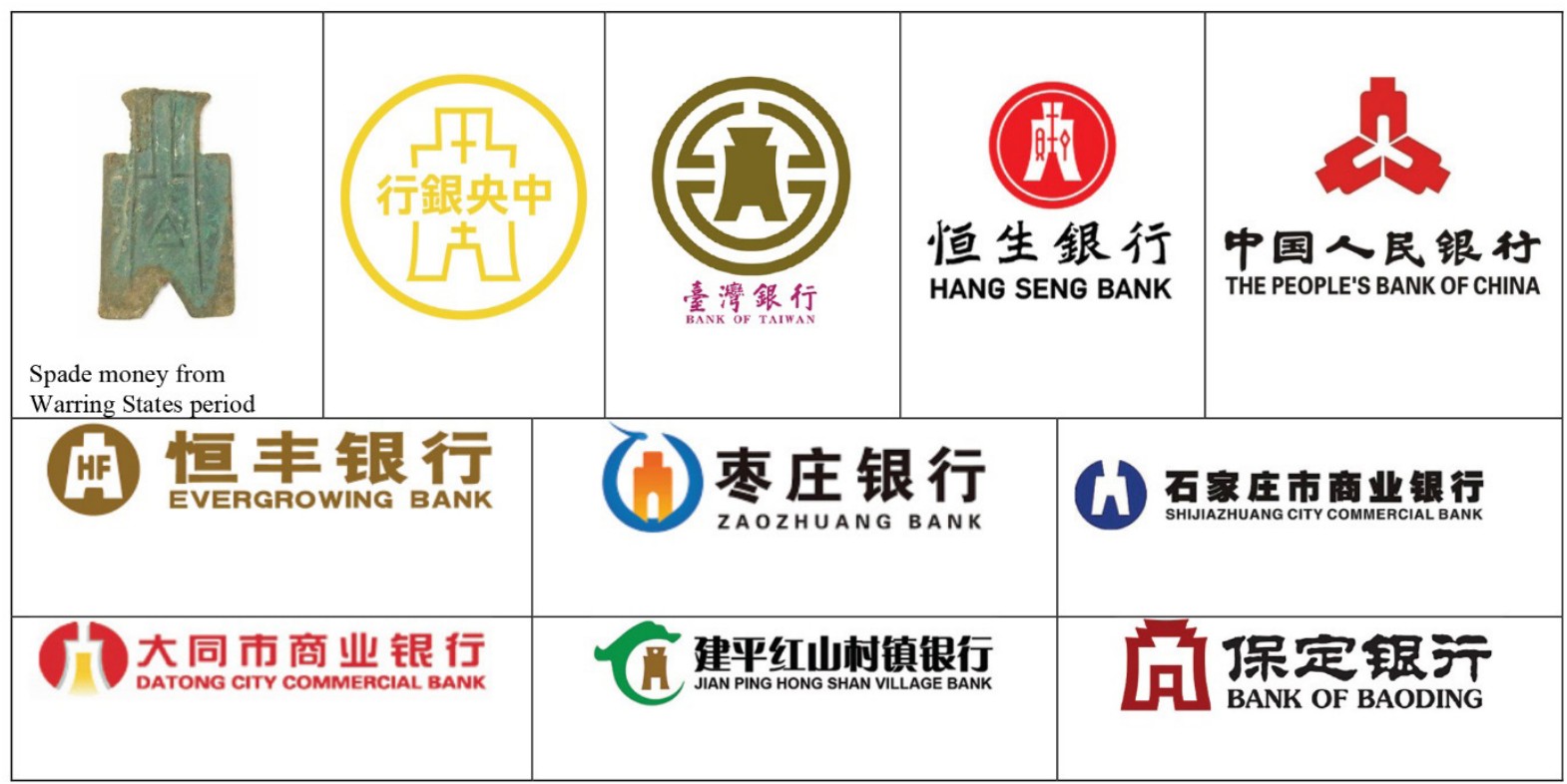

Figure 6 Example of Banks' Logos in China 5

As discussed above, banks' logo design in the Greater China region is strongly influenced by Feng Shui culture. Thusly, it is no surprise to see the analogous visual representation of a bank logo in this region. Culture shapes how people perceive the world. As such, there can be a tremendous difference in how people from different cultures and regions receive and interpret information. For design, what people regarded as 'good' or 'bad' design has a strong influence on their cultural identity and societies. In the case of the Symbolic Feng Shui logo, people expect not only an appealing visual but also a visualization of Feng Shui culture and its symbolism. Therefore, Symbolic Feng Shui logo that winning customers' hearts and minds, must be a design that strongly embodied the concept and visual clues of Feng Shui. By and large, the Symbolic Feng Shui logo is a creation formed on the expression of Feng Shui culture in logo design. It is essentially a "form follows culture" design principle that associated with Feng Shui culture.

In Mainland China, apart from central and southern regions, where Symbolic Feng Shui logo is widely seen in banks' logos. The art of Feng Shui also demonstrated its great influence in autonomous regions such as Xinjiang Uygur, Inner Mongolia, and Tibet. For instance, in the Islamic culture dominated region - Xinjiang Uygur, the 
Bank of Urumqi's logo presented an ancient Chinese coin graphic with dynamic graphical elements to express a strong Feng Shui dynamic. For the Bank of Tibet, the logo design brilliantly transformed the shape of the ancient Chinese coin into a graphic to represent the holistic snow mountain of Tibetan plateau. Meanwhile, the logo of Bank of Inner Mongolia integrated the graphics of ancient Chinese coin and Mongolian horsehead fiddle (Morin Khuur) to represent good Feng Shui and Mongolian cultural identity. In brief, besides the Han majority ethnic group, minority ethnic groups in the greater China region also absorbed the Feng Shui culture into banks' logo design.

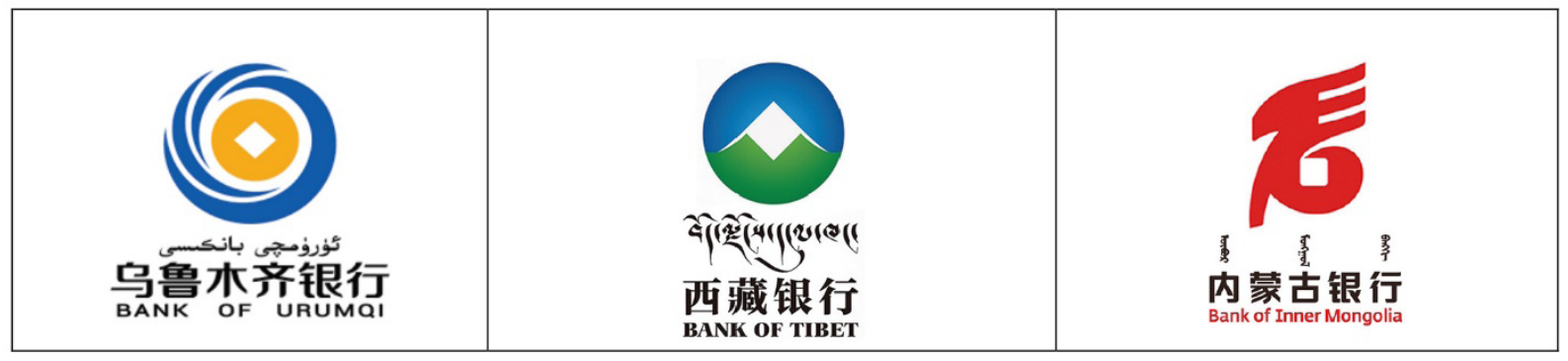

Figure 7 Banks' logos in Urumqi, Tibet, and Inner Mongolia

In addition to the Greater China region, Feng Shui culture travel along with generations of Chinese immigrants to the neighboring countries. At present, apart from the Greater China region, the practice of Symbolic Feng Shui in the logo can be seen in many countries in Southeast Asia as well. For instance, in Vietnam, from the public to commercial banks, the ancient Chinese coin has been the prime Feng Shui element and visual representation of their banks' logo design. As a country that was remarkably influenced by the Chinese culture and tradition, it is no surprise to see the impact of the Symbolic Feng Shui logo is taken a significant place in Vietnam.

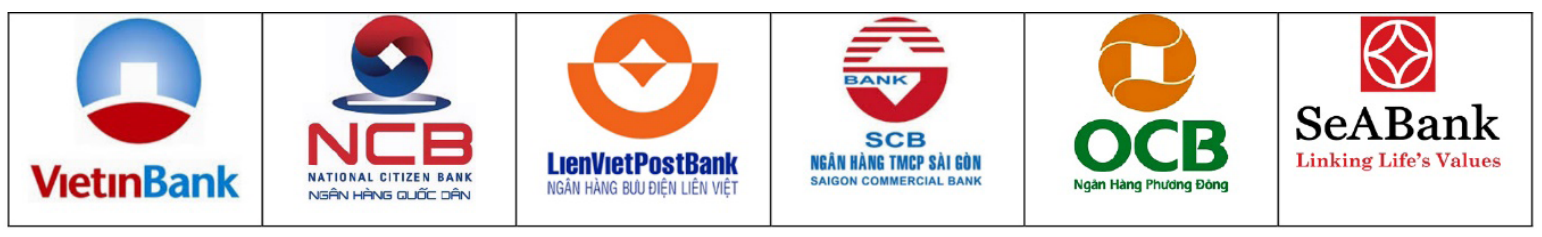

Figure 8 Banks' logos in Vietnam

Meanwhile, banks in Cambodia, Laos, Thailand, and Myanmar also exhibited the influence of Feng Shui. For instance, Canadia Bank in Cambodia, LaoViet Bank (joint venture bank) of Lao and Vietnam, Kasikorn Bank in Thailand, Shwe Bank in Myanmar and Oversea Chinese Banking Corporation, all displayed a strong influence of Feng Shui in their logo design.

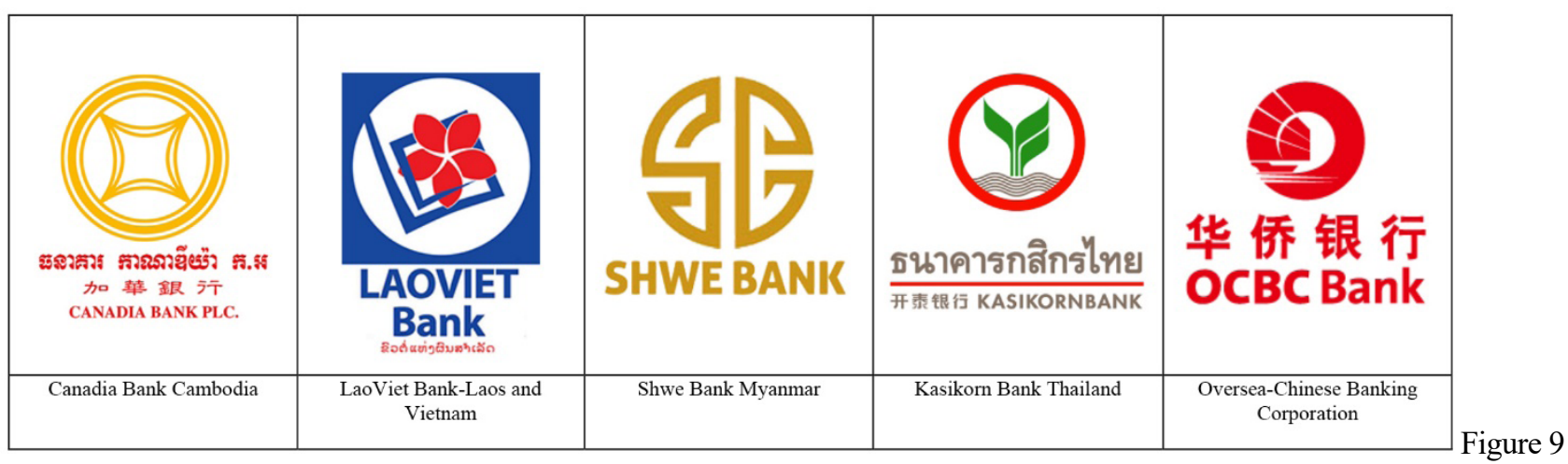

Bank logos in Cambodia, Laos, Myanmar, Thailand, and Singapore

Over the years, the art of Feng Shui has made a great impact on bank logo design in the Greater China region. Evidence has shown that most of the banks' logo visual identity reflects and shapes by principles of Feng Shui. As Feng Shui continues to play an important role in this region, designers in the communication design discipline need to study Feng Shui to understand the cultural and aesthetic preference of clients and audiences in the Greater China region. 


\section{CONCLUSION}

Kacharia (2019), symbols are a big part of a culture as it depicts a pictorial representation of something that they stand for or some following. Thusly, visual symbolism in a logo design needs to be attentively studied in order to communicate effectively towards audiences from certain cultural contexts. Different cultures attach their value and meaning to certain symbols and colors, and these elements are often used as a metaphor in design. Consequently, a well-design logo is necessary to have the audience's cultural context in mind to associate relevant cultural symbolism into the design. People are influenced by their cultural norms and tradition. Hence, if a company failing to create a logo that able to reflect the social attributes of its target audience, it may suffer considerably (Robert, 2014). In the context of the global market-local design era, designers need to be conscious of their audiences' geographical and cultural characteristics. For instance, in Asia, particularly in the Greater China region, Feng Shui undoubtedly is a cultural element that required designers to take into consideration.

According to Robert (2014), every geographical region and culture has a specific emotion or characteristic attached to it. Thus, in order to design a successful logo that immediately strikes to a prospective audience, the design must spell out what the company does and able to resonate with the social, cultural and geographical features of the targeted region. In the case of the Symbolic Feng Shui logo, it is no surprise to see its high popularity in the Greater China region. Since Feng Shui is among the most influential traditional elements in toady's Chinese culture. Redding (2013), similar to a good movie, a well-designed logo is capable of communicating on a variety of levels. Accordingly, a 'right' Symbolic Feng Shui logo not only serves as the company's identity; it can be used to trigger the unconscious-level of audience cultural psychology, and most importantly to connect audience cultural loyalty of the brand. Logo design around the world has similarities. Images, colors, fonts, and symbols are usually included and commonly used by designers worldwide. However, in the context of "Form follows Culture", apart from those common elements, Feng Shui is another significant aspect that requires designers from the Greater China region to take into serious consideration.

\section{REFERENCES}

Afzal, A. (2017). How culture influences design. Retrieved from http://Creativeword.uk.com/blog/localization/culture-influences-design

Ashkenazy, G. (2013). Chinese coins and bank logos. Retrieved from http://primaltrek.com/blog/2013/02/10/chinesecoins-and-bank-logos/

Baldwin, C. D. (2016). Till death do us part 'filthy rich'. Retrieved from https://www.kickstarter.com/projects/literaturist/ til-death-do-us-part-filthy-rich

Bao, Y., et al. (2016). Aesthetic preferences for eastern and western traditional visual art: Identity matters, Frontiers in Psychology. Retrieved from https://www.ncbi.nlm.nih.gov/pmc/articles/PMC5071313/

Beauchesne, M. (2014). Simple feng shui tips for everyday life. Retrieved from http://kheopsinternational.com/blog/ simple-feng-shui-tips-for-everyday-life/

Bruyn, S. T. (2002). Art and aesthetics in action. Retrieved from https://www2.bc.edu/severyn-bruyn/Critique.html

Carlson, D., \& Richards, B. (2011). Design+culture: A return to fundamentalism, David Report, no. 13. Retrieved from http://davidreport.com/the-report/design-culture-time-cultural-fundamentalism/

Chen, G.- M. (2007). The impact of feng shui on Chinese Communication, China Media Research, vol. 3, no. 4, pp. 102-109.

Cisek, J. (2015). Top feng shui tips for auspicious business cards design and why the business card is as mighty as the samurai sward?. Retrieved from http://www.fengshuilondon.net/feng-shui-tips-for-business-cards/topfeng-shui-tips-for-auspicious-business-cards-design-and-why-the-business-card-is-as-mighty-as-the-samurai-sward

Craven, J. (2019). The meaning of 'form follows function': The famous architectural phrase said design should reflect activities. Retrieved from https://www.thoughtco.com/form-follow-function-177237

Du Gay, P., et al. (2013). Doing cultural studies: The story of the Sony Walkman, $2^{\text {nd }}$ edition, Los Angeles, CA: Sage 


\section{Publications.}

Hormia, R. (2018). Form follows culture? - Exploring a design-driven cultural strategy process for new venture brand identity revitalisation. Case: Kämmen, a Nordic accessory brand, Master's thesis, Aalto University. Retrieved from https://aaltodoc.aalto.fi/handle/123456789/36115?locale-attribute=en

Jeremiah. (2010). Form follows function - but should it? Retrieved from https://bitchinarch.wordpress.com/2010/10/25/ form-follows-function-but-should-it/

Kacharia, N. (2019). Why designers must know that culture influences UX?, Retrieved from https://blog.templatetoaster.com/designers-must-know-culture-influences-ux/

Kleijn Brand Agency. (2015). Form follows function or form follows context? . Retrieved from http://www.flaviokleijn. com/blog/2015-03-19-form-follows-function-or-form-follows-context/

Lee, K. P. (2004). 'Design methods for cross-cultural collaborative design project', in J. K. Redmond, D. Durling \& A. De Bono (eds.), Proceedings of Design Research Society International Conference, Melbourne Vic Australia: Monash University.

Lin, R. T. (2007). Transforming Taiwan aboriginal cultural features into modern product design: A case study of a cross-cultural product design model, International Journal of Design, vol. 1, no. 2, pp. 45-53.

Redding, D. (2013. Subconscious meaning in logo design. Retrieved from http://www.magneticstate.com/blogdept/ logo-design-conscious-meaning-versus-subconscious-meaning/

Robert, A. (2014). Cultural and geographical influences on logo designing. Retrieved from http://designrfix.com/logo/ cultural-geographical-influences-logo-designing

Seligman, J. (2013). Form follows culture. Retrieved from http://www.neverwhatyouthink.com/form-follows-culture/

Spacey, J. (2016). What is form follows function?. Retrieved from https://simplicable.com/new/form-follows-function

Tchi, R. (2019). Feng shui tips for the design of business logo. Retrieved from https://www.thespruce.com/feng-shuitips-for-the-design-of-business-logo-1274776

Wu, S. (2018). How is 'form follows function'to $21^{\text {st }}$ century design? . Retrieved from https://uxdesign.cc/how-is-formfollows-function-to-21st-century-design-335737a73305 